\title{
Service Quality And Satisfaction Patient As A Key To Enhance Loyalty Patient Dentist In Bungo Regency (Study Of Patient Health Bpjs Rinsan Manik)
}

\author{
Nur Ika Effendi ${ }^{1 *}$, Marthika ${ }^{2}$, Delila Fitri Harahap ${ }^{3}$ \\ \{yumeika0711@gmail.com* ${ }^{*}$ g \\ ${ }^{1,2,3}$ Departement of Economic, Muara Bungo University, Jambi, Indonesia
}

\begin{abstract}
Service quality and satisfaction on patient could be effectively utilized to strengthen the loyalty of patient. Previous study were focused more on the impact, but in this study aims to give evaluate empirically the impact of service quality and satisfaction of patient dentist health care of BPJS (Institution of Social Security). With data collected 95 patient exploring the patient arrival rate, and the data were analyzed using path analysis. The result reveals the significant had effect of service quality to satisfaction and loyalty of patient. But indirect effect of service quality on loyalty patient trough satisfaction is more than direct effect of service quality to loyalty dentist health care of BPJS. The result of both service quality and satisfaction as well as their interactive effects on loyalty. The managerial and research implications of the reported study are. Therefore, dental clinic Rinsan Manik should develop an service quality especially the dimension of tangible to improve word of mouth.
\end{abstract}

Keywords : Service quality, satisfaction, loyalty, BPJS.

\section{Introduction}

Public awareness toward the importance of health insurance is currently growing up before the government cooperates with the National Social Insurance Agency (Health BPJS). At that time, the National Social Insurance Agency (Health BPJS) was still named as PT. Askes, which could only serve membership in groups / companies, but after the Government collaborated with Health BPJS, 74\% of the Bungo district population has been registered as the insurance participant (BPJS Kesehatan Muara Bungo Branch, 2017).

The enhancement of public awareness toward the healthcare along with the development of demand for First Level Health Facilities (FKTP) which is part of the collaboration with Health BPJS. It brought the impact toward the community that critically comparing the quality of each doctor's medical practice service. Since the amount of doctors who work with Health BPJS were increase, consumers could compare services of each doctor and recommended the good doctor with the good services that they got to people they know, Kurtz and Clow (1998). Thus, every health practice agency in collaboration with Health BPJS must continue to improve the quality of its services. Based on the interviews of researcher with several patients, the treatment that using the Health BPJS service has complicated procedures (it must use a referral letter from a family doctor and has limited services).

Service quality is closely related to customer perception toward business quality, the better services provided will affect the level of customer's satisfaction so that the business will be considered more qualified, (Tjiptono, 2008). (Parasuraman and Valarie A. Zeithmal, 1988), (Badjamal, 2013), (Effendi, 2016) and (Amin, 2008) identified five dimensions of service quality measures that known as SERVQUAL, namely reliability, responsiveness, assurance, 
tangibles, and empathy. Customer's satisfaction is the basis philosophy of a business in creating the value for customer (Sawitri, Yasa and Jawas, 2013). Customer satisfaction or dissatisfaction is the customer's response to the evolution of discrepancies (disconfirmation) between previous expectation and the actual performance of the perceived product, (Rahmawati, 2013). A good relationship between company and consumer can create an advantage, both for company and consumer by providing high quality and excellent service, (Effendi, 2016). Previous research also found that service quality had an effect on student satisfaction at universities in Bungo District (Effendi, 2016). It can also apply to dentist health facility that also supports health services.

Health Facilities of medical practitioner, especially dentist in collaboration with Health BPJS in Bungo district currently consists of 3 (three) First Level Health Facilities (FKTPs) / medical practitioner. With many medical practitioners collaborate with Health BPJS is expected in order the Health BPJS insurance participants have the choice to register or get health services according to what they want.

Rinsan Manik's dental medical practice is a Health Facility (Faskes) of dentist that first collaborated with Health BPJS that provides dental and oral medical services. The dentist clinic is open every weekday with service time of 6 days a week starting at 16.00-21.00 WIB (western indonesia time). The Health BPJS patient simply shows the Health BPJS card and is registered as a member of the Rinsan Manik dentist family doctor without the need to take a referral from a medical general practitioner / family doctor. Although Rinsan Manik's dental medical practice is the first FKTP in dental and oral services does not mean this doctor's practice is the first choice in consumer's mind, especially the Bungo community. Moreover, the Rinsan Manik business place is still in a shophouse that does not yet have adequate facilities for front liner. The waiting room does not yet have air conditioner and the patient data collection system is still manual. Based on interviews with several patients, with the limitations possessed by the Rinsan Manik dentist in terms of the tangible side, in terms of the reliability of the doctor can compete with other doctors. Likewise, in terms of services, both the medical team and the administration side are indeed responsive to patient. The data that can be accessed when the research is conducted through the application pcare.BPJSKesehatan.go.id in January-December 2017 can be seen in table 1

Table 1. The Amount of Health BPJS Participant and Visit in Rinsan Manik Dentist Practice

\begin{tabular}{llll}
\multicolumn{3}{c}{ on July-December 2017 } \\
\hline No & Month & $\begin{array}{c}\text { The Amount of } \\
\text { Health BPJS } \\
\text { Participant }\end{array}$ & $\begin{array}{c}\text { The Amount } \\
\text { of Patient } \\
\text { Visit }\end{array}$ \\
\hline 1 & July & 20.186 & 321 \\
\hline 2 & August & 20.397 & 346 \\
\hline 3 & September & 20.296 & 158 \\
\hline 4 & October & 20.405 & 287 \\
\hline 5 & November & 20.374 & 375 \\
\hline 6 & December & 20.812 & 268 \\
\hline \multicolumn{3}{c}{ Total } & 1.755 \\
\hline
\end{tabular}

Based on table 1, the amount of Health BPJS participants and the amount of visit in the dental medical practice of Rinsan Manik on July-December 2017, there were fluctuation in the number of registered members and also patients who visited. Dentist Rinsan Manik's medical practice as a provider of health services inevitably has to face competition with many similar 
medical practices. This research needs to be done because the first research related to Dentist Medical Practices in Bungo Regency, and Rinsan Manik is one of the first dental medical practices that must be aware to the quality of its services in order to create patient satisfaction that can bring the impact on patient loyalty. For this reason, we need a customer-minded concept where focus on the needs of patients.

This study analyzes how the quality of service and satisfaction have a partial and simultaneous effect on the loyalty of Health BPJS patients in Dentist Practices in Bungo Regency and see how service quality influences the loyalty of Health BPJS Patients through patient satisfaction in Dentist medical Practice in Bungo District.

\section{Theoretical Framework}

\subsection{Service Quality}

Service quality can be defined as a customer's assessment of the superiority or privilege of a product or service as a whole, as well as the form of an attitude that is related but not the same as satisfaction, and this is the result of a comparison between expectations with the action, Zeithaml and Parasuraman (1988: p.3 ) In his research, he mentioned five important dimensions that determine the level of service quality, that are tangible, reliability, responsiveness, assurance, empathy, (Parasuraman and Valarie A. Zeithmal, 1988),(Effendi, 2016).

If the patient receives or feels service as expected, the perceived quality is good and satisfying. If it is received beyond the expectation of service users, the quality of services is perceived as the ideal quality. Conversely, if the service received is lower than expected, the quality of services is perceived poorly (Wusko, 2014), The better the quality of care provided, the better the level of patient satisfaction. So by providing high quality and excellent service, this becomes the wish of satisfied and loyal customers.

\subsection{Customer Satisfaction}

Every action or wish carried out by a company that aims to satisfy consumer can be directly felt by customer, so that customer can immediately concludes whether they are satisfied or not satisfied in receiving services. The pleasure feeling or disappointment that arise after comparing the performance (result) that is thought of the performance expected (or result) by Kotler (2014). Customer satisfaction is the cognitive situation of the buyer with regard to equivalence or incompatibility between the result obtained compared to the sacrifice that has been made, especially when associated with perceived service quality. Satisfaction is also a conscious evaluation or cognitive research concerning whether the product performance is relatively good or bad or whether the product in question matches or does not match to the purpose or usage (Tjiptono, 2014). According to Tjiptono and Chandra (2012), customer satisfaction provides two main benefits for company, which is in the form of customer loyalty and distribution (advertising) by word of mouth. The research that is in line with this theory is (Effendi, 2016) where the result of his research that inpatient satisfaction at $\mathrm{H}$. Hanafie Hospital is needed in improving the quality of work and also the quality of service from the resources owned by $\mathrm{H}$. Hanafie Bungo Hospital.

\subsection{Loyalty}

According to Tjiptono, (2008) loyalty is a situation where consumer acts positively toward the product or producer (service provider) and accompanied by a consistent repurchase 
pattern. Likewise, Zabkar, Vesna, (2000), Stephen, Maznah, et c. 2007, and the research by(Effendi 2016) said that it turned out that the service quality of Muara Bungo University had no effect on student loyalty. It means that students chose and remained in college despite it has low service quality, but there are supporting factors such as the only university in Jambi in the West district which has caused not to move to another University around Bungo.

While the research of Utami and Christina, (2006) Nugroho and Paramitha, (2009), said that loyal consumer is an important method in maintaining profit from competitor, considering having loyal consumer means consumer would not become customer for competitor.

\subsection{The Relationship of Service Quality, Satisfaction and Loyalty}

Service Quality is one of the most important things from several marketing activities because service quality is expected to help organization to achieve the goal of a company in creating loyalty through customer satisfaction, (Effendi 2016). Where the result of his research there is a positive influence between the quality of service, institution image, satisfaction with the loyalty of the students of the Economy Faculty of Muara Bungo University. Similarly, (Widya Chitami Puti, 2013) study showed that there was a positive relationship between service quality and patient satisfaction with outpatient loyalty and inpatient care at the Batam Authority Hospital. Ritna Rahmawati Dewi, (2016) study found it too.

The hypothesis of this study is as follow:

$\mathrm{H} 1 . \mathrm{H}_{0}$ : There is no influence on the service quality on Health BPJS patient satisfaction in Dentist Medical Practice in Bungo District

$\mathrm{Ha}$ : There is influence on the service quality on Health BPJS patient satisfaction in Dentist Medical Practice in Bungo District

H2. $\mathrm{H}_{0}$ : There is no influence of Patient Satisfaction on Patient Loyalty of Health BPJS in Dentist Medical Practices in Bungo District

$\mathrm{Ha}$ : There is influence of Patient Satisfaction on Patient Loyalty of Health BPJS in Dentist Medical Practices in Bungo District

H3. $\mathrm{H}_{0}$ : There is no effect on the service quality on Health BPJS Patient Loyalty in Dentist Medical Practices in Bungo District

$\mathrm{Ha}$ : There is no effect on the service quality on Health BPJS Patient Loyalty in Dentist Medical Practices in Bungo District

H4. $\mathrm{H}_{0}$ : There is no effect of Service Quality on Patient Loyalty through Health BPJS Patient Satisfaction in Dentist Medical Practices in Bungo District

Ha : There is effect of Service Quality on Patient Loyalty through Health BPJS Patient Satisfaction in Dentist Medical Practices in Bungo District

\section{Research Methodology}

\subsection{Definition and Measurement of Variables}

We summarize the operational definition and measurement of variables for validation of the research hypotheses in table 2

Table 2 . Operational Definition and Measurement of Variables

\begin{tabular}{lll}
\hline Variable & \multicolumn{2}{c}{ Definition } \\
\hline Service & Service quality is the .. Tangibles (Physical \\
quality & expectation of excellence evidence) \\
(X) & level and the control of the ?. Reliability \\
\hline
\end{tabular}




\begin{tabular}{|c|c|}
\hline & $\begin{array}{l}\text { excellence level to meet i. Responsiveness } \\
\text { customer's wish. (Zeithaml l.Assurance } \\
\text { and Parasuraman, (1988: i.Empathy } \\
\text { p.3), (Tjiptono, 2008), } \\
\text { (Effendi, 2016) }\end{array}$ \\
\hline $\begin{array}{l}\text { Consumer } \\
\text { Satisfacti } \\
\text { on } \\
\text { (Y1) }\end{array}$ & $\begin{array}{l}\text { Statisfication is a feeling .. Quality is given as } \\
\text { that shows happiness or promised } \\
\text { disappointment that appear :. Good service and } \\
\text { after comparing the satisfaction } \\
\text { performance (result) of patients } \\
\text { product that is thought of the } \\
\text { expected performance (or } \\
\text { result). (Kotler, 2014) }\end{array}$ \\
\hline $\begin{array}{l}\text { Consumer } \\
\text { Loyalty } \\
\text { (Y2) }\end{array}$ & $\begin{array}{l}\text { Loyalty is a situation where } 1 \text {. } \\
\text { consumer acts positively Loyalty } \\
\text { about the product or } 2 \text {. Not } \\
\text { producer (service provider) affected by the } \\
\text { and accompanied by product of other } \\
\text { consistent buying dentist medical } \\
\text { pattern.(Tjiptono, 2008) }\end{array}$ \\
\hline
\end{tabular}

\subsection{Data Collection and Analysis}

The data collection method uses a questionnaire distribution technique that has been prepared in the form of an ordinal scale based on the Likert Summated Rating. The population in this study was that patients in Rinsan Manik's Dentist Practice were calculated based on the number of patients who visited / treated at Rinsan Manik's Dentist Practice in July-December 2017 as many as 1,755 patients. The number of samples in this study with the error rate that was tolerated was equal to $10 \%$, so the number of respondent was set at 95 respondents. The sampling technique in this study was purposive proportional random sampling. Those who were more than 2 times treated at the Dentist Rinsan Manik practice and were able to fill out the questionnaire. Processing data with path analysis assisted with SPSS 23.

The equation in this model is :

1) $Y_{1}=b_{1} X+e_{1}$

2) $Y_{2}=b_{1} X+b_{1} Y_{1}+e_{2}$

information :

$\mathrm{Y}_{1}$ : Satisfaction on Patient

$\mathrm{Y}_{2}$ : Loyalty of Patient

$\mathrm{X}$ : Service Quality 
$\mathrm{b}_{1}$ : coefisient regression of service quality

$\mathrm{e}_{1}, \mathrm{e}_{2}:$ Residual

The following is a picture of the path analysis model in this study:

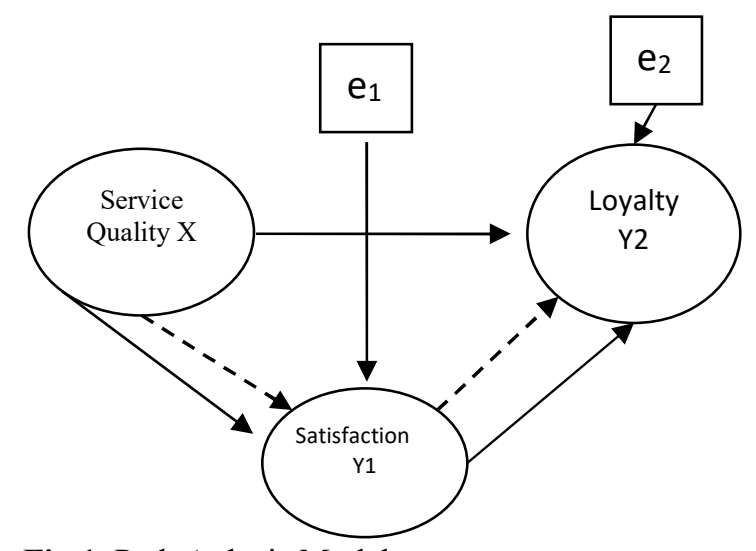

Fig.1. Path Anlysis Model

\subsection{Validity and Reliability}

We analyzed the validity on units variables remaining after discarding items disturbing the homogeneity of the set, indicated that they generally satisfied validity evaluation standards. The results were all statement items in valid, where the correlation value ( $\mathrm{r}$ table) was greater than the value 0.202 ( $\mathrm{r}$ table). Next, we analyzed internal consistency of the sample to check the reliability of our data. The reliability analysis of each variables result produced the following result : service quality : 0,857 , satisfaction : 0,715 , loyalty 0,747 . Cronbach's alpha value for all variables was over 0.7 , indicating reliability level. This can be seen in tables 3 and 4 .

Tablel 3. Validity All Variable

\begin{tabular}{|c|c|c|c|}
\hline Item & Corelation $\left(\mathrm{r}_{\text {hitung }}\right)$ & $\mathrm{r}_{\text {tabel }}$ & Ket \\
\hline \multicolumn{5}{|c|}{ X1 Service Quality } \\
\hline KL 1 & 0,554 & 0,202 & Valid \\
\hline KL 2 & 0,679 & 0,202 & Valid \\
\hline KL 3 & 0,710 & 0,202 & Valid \\
\hline KL 4 & 0,586 & 0,202 & Valid \\
\hline KL 5 & 0,699 & 0,202 & Valid \\
\hline KL 6 & 0,695 & 0,202 & Valid \\
\hline KL 7 & 0,660 & 0,202 & Valid \\
\hline KL 8 & 0,653 & 0,202 & Valid \\
\hline KL 9 & 0,786 & 0,202 & Valid \\
\hline KL10 & 0,639 & 0,202 & Valid \\
\hline \multicolumn{5}{|c|}{ Y1 Satisfaction } \\
\hline KP 1 & 0,396 & 0,202 & Valid \\
\hline KP 2 & 0,459 & 0,202 & Valid \\
\hline KP 3 & 0,283 & 0,202 & Valid \\
\hline KP 4 & 0,406 & 0,202 & Valid \\
\hline
\end{tabular}




\begin{tabular}{|c|c|c|c|}
\hline Item & Corelation ( $\left.\mathrm{r}_{\text {hitung }}\right)$ & $\mathrm{r}_{\text {tabel }}$ & Ket \\
\hline \multicolumn{4}{|c|}{ Y2 Loyality } \\
\hline LY1 & 0,705 & 0,202 & Valid \\
\hline LY 2 & 0,673 & 0,202 & Valid \\
\hline LY 3 & 0,483 & 0,202 & Valid \\
\hline LY 4 & 0,470 & 0,202 & Valid \\
\hline LY 5 & 0,412 & 0,202 & Valid \\
\hline LY 6 & 0,445 & 0,202 & Valid \\
\hline LY 7 & 0,646 & 0,202 & Valid \\
\hline LY 8 & 0,729 & 0,202 & Valid \\
\hline
\end{tabular}

Table 4: Reliability

\begin{tabular}{|c|c|c|c|}
\hline Item & $\begin{array}{c}\text { Cronbach } \\
\text { Alpha }\end{array}$ & $\begin{array}{c}\text { N Of } \\
\text { Item }\end{array}$ & Ket \\
\hline $\begin{array}{c}\text { Service Quality } \\
\text { (X) }\end{array}$ & 0,857 & 10 & Reliabel \\
\hline $\begin{array}{c}\text { Satisfaction } \\
\text { (Y1) }\end{array}$ & 0,715 & 4 & Reliabel \\
\hline Loyality (Y2) & 0,747 & 8 & Reliabel \\
\hline
\end{tabular}

\section{Results And Discussion}

\subsection{Hypotesis Test}

Based on research the coefficient can be made a test of direct influence and indirect effects, namely:

1. Equation path coefficient 1

Referring to the regression output of equation 1 in the part of the coefficient table, it can be seen that the significance value of the variable $X$ is: 0,000 less than 0.05 . This result concludes that equation 1 , namely $\mathrm{X}$ variable has a significant effect on $\mathrm{Y}$ variable. The value of $\mathrm{R} 2$ or $\mathrm{R}$ square in the summary table model is 0.479 , this indicates that the contribution of the effect of variable $\mathrm{X}$ to $\mathrm{Y}$ variable is $47.9 \%$. While the remaining $52.1 \%$ is a contribution from other variables that not included in this research. Meanwhile, for the value el can be searched by formula $e_{1}=\sqrt{1-R^{2} Y_{x}} e_{1}=\sqrt{1-0,479}=0,7218$. Thus a path diagram for equation 1 is obtained.

2. Equation path coefficient 2

Referring to the regression output of equation 2 in the part of the coefficient table, it can be seen that the significance value of the variable $\mathrm{X}$ is: 0,000 and variable $\mathrm{Y} 10.016$ which is smaller than 0.05 . This result gives the conclusion that equation 2 , which is the variable $X$ and variable $\mathrm{Y} 1$, have a significant effect on the variable $\mathrm{Y} 2$. The value of $\mathrm{R} 2$ or $\mathrm{R}$ square contained in the table summary model is 0.479 , this indicates that the contribution of the effect of variable $\mathrm{X}$ to $\mathrm{Y}$ variable is equal to $47.9 \%$ while the remaining $52.1 \%$ is the contribution of other variables not included in this research. Meanwhile, for e2 values can be searched by formula $e 2=\sqrt{1-R^{2} Y_{x}} e 2=\sqrt{1-0,514}=0,6971$. Thus the path diagram of equation 2 is obtained. 


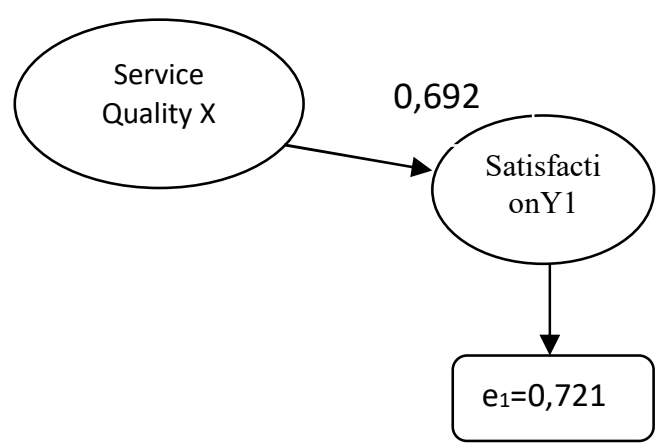

Fig. 2. Path Analysis Model II

3. Equation path coefficient 2

Referring to the regression output of equation 2 in the part of the coefficient table, it can be seen that the significance value of the variable $\mathrm{X}$ is: 0,000 and variable $\mathrm{Y} 10.016$ which is smaller than 0.05 . This result gives the conclusion that equation 2 , which is the variable $X$ and variable $\mathrm{Y} 1$, have a significant effect on the variable Y2. The value of R2 or R square contained in the table summary model is 0.479 , this indicates that the contribution of the effect of variable $\mathrm{X}$ to $\mathrm{Y}$ variable is equal to $47.9 \%$ while the remaining $52.1 \%$ is the contribution of other variables not included in this research. Meanwhile, for e2 values can be searched by formula $e 2=\sqrt{1-R^{2} Y_{x}} e 2=\sqrt{1-0.514}=0,6971$. Thus the path diagram of equation 2 is obtained.

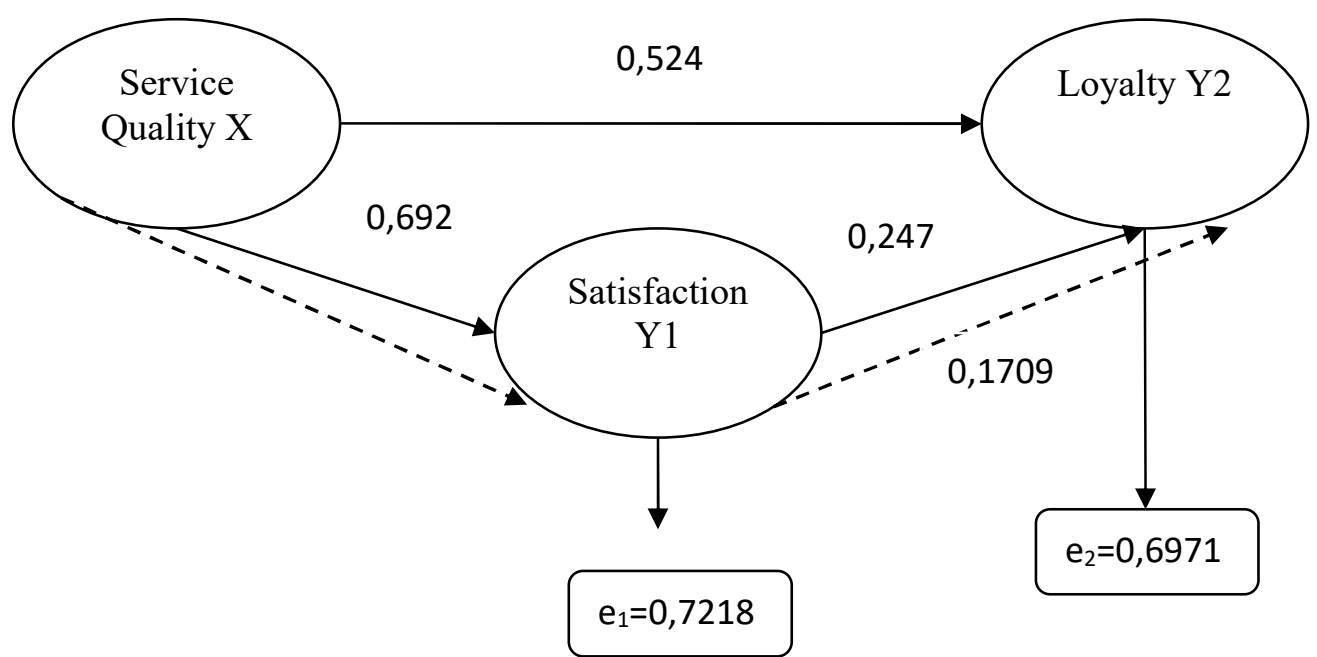

Fig. 3. Path Analysis Model II 
Based on the picture 2 and 3 path analysis model can be seen that the results of testing the hypothesis of this study are:

The test hypothesis 1 , which shows the effect of variable service quality direct effect on satisfaction.

The test hypothesis 2, which shows the effect The Analysis of the effect of satisfaction on loyalty. It obtained a significance value of $0.016<0.05$. So that it can be concluded that there is direct effect of satisfaction on loyalty.

The test hypothesis 3, which shows the effect The Analysis of service quality on loyalty it obtained a significance value of $0.000<0.05$. So that it can be concluded that there is direct effect of service quality to variable satisfaction.

The test hypothesis 4, which shows the effect. The Analysis of The Effect of service quality through satisfaction on loyalty. It is known that the direct effect given service quality service quality to satisfaction is 0.524 . While the indirect effect of service quality through satisfaction on loyalty is the multiplication of the value of beta satisfaction to loyalty, namely: $0.692 \times 0.247=0.170$, the total effect given service quality to loyalty is a direct effect with indirect effect namely: $0.524+0.170=0.694$. Based on the result of the calculation above, it is known that the direct effect value is 0.524 and the indirect effect is 0.694 which mean that the indirect effect value is greater than the direct influence value, this result showed indirectly that service quality through satisfaction has an influence on satisfaction.

\section{Conclusion}

Based on the analysis and discussion of the result of hypothesis testing that has been done, it was proposed several important conclusions which are the core of the result in this study. $\left(\mathrm{H}_{1}\right.$ was accepted). The result of testing the second hypothesis found that patient satisfaction had a significant effect on patient loyalty in using the services of Rinsan Manik's Dentist Medical Practice, the better and consistent quality of services provided, the more the patient's commitment to use practice services $\left(\mathrm{H}_{2}\right.$ was accepted $)$.

Based on the result of testing the third hypothesis, it was found that service quality had a significant effect on patient loyalty in using the services of Dentist Medical Practice $\left(\mathrm{H}_{3}\right.$ was accepted). Based on the result of testing the fourth hypothesis it was found that service quality had a significant effect on patient loyalty which was mediated by patient satisfaction in using the services of Dentist Rinsan Manik. ( $\mathrm{H}_{4}$ was accepted).

There are number of limitations that the researchers felt in this study that is the limited scope of patient in the Rinsan Manik Dentist Medical Practice , even though there are still other dental medical practices or the practice of doctors outside the dentist so that in order to obtain general conclusion, more extensive research is needed by expanding the object of research. This study only examined the effect of service quality and patient satisfaction, even though there are still other factors outside of research that can affect patient loyalty.

\section{Suggestion}

Based on the conclusions and limitations that exist in this study, it can be suggested as follows:

1. Practice Management Dentist Rinsan Manik is advised to strive to continue to maintain and improve the quality of services they will provide to patients,

2. Future researchers are advised to increase the number of samples to be used, and try to add at least one other variable which is suspected to also influence the formation of patient 
loyalty, namely attitudes. In addition, researchers in the future must try to use different observation areas. improve the accuracy of research results in the future.

\section{References}

[1] Amin, S. A. \& N. (2008) 'Pengaruh Kualitas Pelayanan, Harga Dan Kepuasan Terhadap Loyalitas Pengguna Jasa Transportasi Pada Po. Bejeu Jepara (Studi Kasus Pada Pengguna Travel Bejeu Jurusan Semarang - Jepara)', Comparative Biochemistry and Physiology - C Toxicology and Pharmacology, 147(1), pp. 36-42. doi: 10.1016/j.cbpc.2007.07.007.

[2] Badjamal, F. A. (2013) 'Pengaruh Kualitas Pelayanan terhadap Kepuasan Konsumen pada Bussines Center Sophie Paris di Kota Parigi’, e-Jurnal Katalogis, 1(2), pp. 122 136.

[3] Effendi, N. I. (2016) Pengaruh Kualitas Kerja dan Kualitas Pelayanan Terhadap Kepuasan Pasien di Rumah Sakit Kabupaten Bungo, Seminar Nasional 'Optimasi Industri Kreatif Untuk Pertumbuhan Ekonomi Nasional yang Berkelanjutan’ 654-663, Padang : Universitas Andalas.

[4] Effendi Nur Ika (2016) 'Analisis Pengaruh Kualitas Pelayanan dan Citra Institusi Terhadap Kepuasan Mahasiswa Untuk Meningkatkan Loyalitas Mahasiswa Fakultas Ekonomi Universitas Muara Bungo', Aplikasi Ekonomi dan Bisnis Vol. 1 No. 1 Agustus 2016 http://ojs.umb-bungo.ac.id/, 1(1).

[5] Kotler. 2014. Manajemen Pemasaran Jasa Edisi 3. Jakarta : Salemba Empat

[6] Parasuraman and Valarie A. Zeithmal (1988) 'SERVQUAL: A Multiple-Item Scale for Measuring Consumer Perceptions of Service Quality, Journal of Retailing, Volume : 64', pp. 12-40. doi: 10.1016/S0148-2963(99)00084-3.

[7] Rahmawati, D. (2013) 'Analisis Faktor-Faktor yang Mempengaruhi Kepuasan Mahasiswa', Jurnal Economia, 9(1), pp. 1-14. doi: 10.21831/Economia.V9I1.1376.

[8] Ritna Rahmawati Dewi (2016) 'Pengaruh Kualitas Pelayanan Terhadap Loyalitas Pasien Pengguna Bpjs Dengan Kepuasan Pasien Sebagai Variabel Intervening Di Rawat Inap Rsu Slamet Riyadi', Universitas Muhammadiyah Surakarta, p. 2016.

[9] Sawitri, N. P., Yasa, N. N. K. and Jawas, A. (2013) 'Pengaruh Kualitas Pelayanan Terhadap Kepuasan Dan Loyalitas Pelanggan Tegal Sari Accommodation Di Ubud', Jurnal Manajemen, Strategi Bisnis, dan Kewirausahaan, 7(1), pp. 40-47.

[10] Puti, Widya Chitami (2013) 'Pengaruh Kualitas Pelayanan Dan Kepuasan Terhadap Loyalitas Pasien Rawat Jalan Dan Rawat Inap Rumah Sakit Otorita Batam.Pdf'. Available

http://repository.widyatama.ac.id/xmlui/bitstream/handle/123456789/2576/widya chitami p 0208149.pdf? sequence $=1$.

[11] Wusko, A. U. (2014) 'Pengaruh Store Environment Terhadap Impulse Buying (Survei Pada Pembeli di Serbu Mart Sukorejo),Jurnal Sketsa Bisnis Vol 1 No . 1 Agustus 2014', 1(1), pp. 1-13.

[12] Sangadji, E.M, dan Sopiah. 2013. Perilaku konsumen : Pendekatan Praktis Disertai himpunan Jurnal Penelitian. Yogyakarta : Andi Offset.

[13] Tjiptono, Fandy. 2008. Service Manajemen, Mewujudkan Layanan Prima. Yogyakarta : Andi. 